\title{
Pengaruh Jalur Penerimaan Mahasiswa Dan Asal Sekolah Terhadap Prestasi Mahasiswa di Fakultas Sains Dan Teknologi UIN Sunan Kalijaga ${ }^{1}$
}

\author{
Mohammad Farhan Qudratullah \\ Program Studi Matematika, Fakultas Sains dan Teknologi, UIN Sunan Kalijaga, JI. Marsda Adisucipto \\ No. 1 Yogyakarta, Indonesia
}

Korespondensi; Email: aching_lo@yahoo.com

\begin{abstract}
Abstrak
Penelitian ini bertujuan untuk mengetahui pengaruh jalur penerimaan mahasiswa dan asal sekolah terhadap prestasi belajar mahasiswa di Fakultas Sains dan Teknologi UIN Sunan Kalijaga. Metode yang digunakan dalam penelitian ini adalah ex post facto dengan desain faktorial 3x2. Hasil penelitian menunjukan bahwa: (1) jalur penerimaan berpengaruh terhadap prestasi mahasiswa, dimana prestasi mahasiswa yang diterima melalui jalur eksternal lebih baik dari jalur internal, (2) asal sekolah berpengaruh terhadap prestasi mahasiswa dimana prestasi mahasiswa yang berasal dari SMU/K lebih baik dari MA/P, dan (3) tidak terdapat interaksi antara kedua faktor tersebut dalam mempengaruhi prestasi mahasiswa.
\end{abstract}

Kata Kunci: Asal Sekolah; Jalur Penerimaan; Prestasi Mahasiswa

\begin{abstract}
This study aims to determine the effect reception path and home school students on student achievement in the Faculty of Science and Technology UIN Sunan Kalijaga. The method used in this research is ex post facto with a $3 \times 2$ factorial design results showed that: (1) reception path effect on student achievement, where the achievements of students accepted through external lines better than internal pathways, (2) the origin school effect on student achievement where achievement of students from $S M U / K$ better than $M A / P$, and (3) there is no interaction between the two factors in influencing student achievement.
\end{abstract}

Keywords: Originally school; Admissions; Student Achievement

\section{Pendahuluan}

Di era globalisasi yang bercirikan high competition ini, tuntutan terhadap perguruan tinggi bukan hanya sebatas kemampuan untuk menghasilkan lulusan yang diukur secara akademik, melainkan keseluruhan program dari lembaga-lembaga perguruan tinggi tersebut harus mampu membuktikan kualitas yang tinggi demi terciptanya manusia Indonesia seutuhnya, yaitu menguasai ilmu pengetahuan dan teknologi (IPTEK), estetika (seni), moral dan etika.

Di Indonesia, tingkat human development index (HDI) yang mengukur pembandingan antara life expectancy, literacy, education, dan standard of living belum beranjak naik secara signifikan, rangking ini tidak berbeda jauh dengan negara Vietnam yang baru merdeka. Pada tahun 2012 Indonesia berada pada peringkat 121 dari 185 negara dan berada di bawah rata- rata PBB. Salah satu cara untuk meningkatkan kualitas hidup adalah dengan terus meningkatkan kualitas Sumber Daya Manusia, yaitu melalui pendidikan.

\footnotetext{
1 Penelitian ini dilaksanakan dalam Rangka Kegiatan Short Course Penelitian Kuantitatif Bidang Pendidikan di Universitas Negeri Jakarta, 18 November 2013 - 18 Februari 2014
} 
Tabel 1 Posisi HDI tahun 2000, 2006, 2012.

\begin{tabular}{lccc}
\hline \multirow{2}{*}{ Negara } & \multicolumn{3}{c}{ Tahun } \\
\cline { 2 - 4 } & $\mathbf{2 0 0 0}$ & $\mathbf{2 0 0 6}$ & $\mathbf{2 0 1 2}$ \\
\hline Thailand & 76 & 74 & 103 \\
Philipina & 77 & 84 & 114 \\
Malaysia & 61 & 61 & 64 \\
Indonesia & 109 & 108 & 121 \\
Vietnam & 108 & 109 & 127 \\
\hline \multicolumn{2}{c}{ Sumber: } & UNDP berbagai edisi
\end{tabular}

Universitas Islam Negeri (UIN) Sunan Kalijaga hadir untuk memenuhi tuntutan masyarakat dan dunia kerja terhadap lembaga pendidikan tinggi yang dapat mengintegrasikan keislaman dan keilmuan serta bermanfaat bagi peradaban. UIN Sunan Kalijaga diharapkan dapat menghasilkan pekerja yang profesional, intelektual yang agamis, dan pemimpin bangsa yang moralis. Kehadiran UIN Sunan Kalijaga merupakan perjuangan panjang umat Islam Indonesia, yang dimulai sejak tahun 1951. Tranformasi IAIN Sunan Kalijaga menjadi UIN Sunan Kalijaga secara de jure, ditandai dengan terbitnya Keputusan Presiden RI Nomor 50 Tahun 2004 tertanggal 21 Juni 2004. Implikasinya dalam aspek akademik, UIN Sunan Kalijaga mendapatkan ijin penyelenggaraan program studi umum di luar ilmu-ilmu keislaman yang ditandai dengan berdirinya 2 (dua) fakultas baru, yaitu Fakultas Sains dan Teknologi dan Fakultas Ilmu Sosial dan Himanora.

UIN Sunan Kalijaga diharapkan dapat menghasilkan pekerja yang profesional, intelektual yang agamis, dan pemimpin bangsa yang moralis. Dengan kata lain, UIN Sunan Kalijaga menginginkan mahasiswa dan lulusannya mampu berprestasi di berbagai bidang, salah satu prestasi yang menjadi perhatian semua intitusi pendidikan adalah prestasi bidang akademik atau sering juga disebut prestasi belajar.

Pasaribu (1983) mendefinisikan prestasi belajar adalah hasil yang dicapai seseorang setelah mengikuti suatu program pendidikan dan latihan. Sedangkan Winke (1996) mengemukakan bahwa prestasi belajar merupakan bukti keberhasilan yang telah dicapai seseorang atau prestasi belajar merupakan hasil maksimum yang dicapai oleh seseorang setelah melaksanakan usaha belajar. Sementara Tirtonegoro (2001) mengemukakan bahwa prestasi belajar adalah penilaian hasil usaha kegiatan belajar yang dinyatakan dalam bentuk simbol, angka, huruf, maupun kalimat yang dapat mencerminkan hasil yang sudah dicapai oleh setiap anak dalam periode tertentu.

Berdasarkan beberapa pengertian di atas dapat didefinisikan bahwa prestasi belajar mahasiswa adalah hasil penilaian dari kegiatan dari kegiatan belajar yang telah dilakukan dan merupakan bentuk perumusan akhir yang diberikan oleh dosen untuk meihat sampai dimana kemampuan mahasiswa yang dinyatakan dalam bentuk simbol, huruf maupun kalimat yang dapat mencerminkan hasil yang sudah dicapai. Prestasi belajar mahasiswa dapat diukur dengan besarnya nilai Indeks Prestasi Komulatif (IPK) Mahasiswa (Skala: 0.00-4.00).

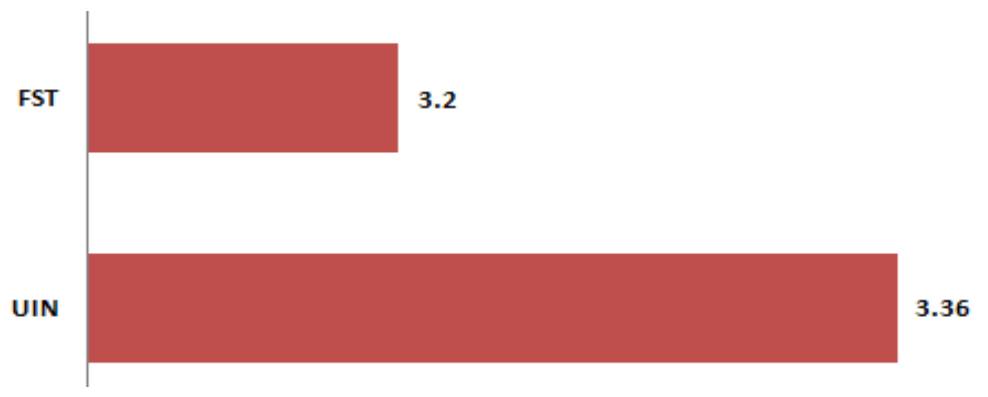

Gambar 1 Perbandingan rata-rata IPK tahun 2013.

Pada tahun 2013, rata-rata IPK lulusan UIN Sunan Kalijaga adalah 3,36 sedangkan rata- rata IPK lulusan Fakultas Sains dan Teknologi adalah 3,20. Tampak bahwa IPK lulusan Fakultas Sains dan Teknologi lebih rendah dibanding IPK lulusan UIN Sunan Kalijaga. 
Gojali dan Umuarso (2011) yang mengatakan bahwa berhasil tidaknya proses belajar siswa mencapai prestasi belajar siswa sebagaimana yang diharapkan, maka perlu diperhatikan beberapa faktor yang yang mempengaruhi prestasi belajar antara lain: faktor yang terdapat dalam diri siswa (faktor intern) dan faktor dari luar siswa (faktor ekstern). Faktor internal meliputi jenis kelamin, umur, nilai NEM, motivasi, dan lainnya, sedangkan faktor eksternal meliputi faktor keluarga yaitu pendidikan dan pekerjaan orang tua, faktor sekolah, yaitu status sekolah dan jalur masuk perguruan tinggi, dan faktor lingkungan, yaitu daerah status tempat tinggal, serta faktor lainnya (Slameto, 2003).

Penelitian ini hanya ingin mengetahui pengaruh faktor sekolah, yaitu jalur masuk perguruan tinggi dan asal sekolah. Jalur masuk UIN Sunan Kalijaga terbagi menjadi 2 (dua), yaitu ujian tulis dan penelusuran mahasiswa berprestasi. Ujian tulis dapat dibedakan menjadi 2 (dua) lagi, yaitu ujian tulis yang diselenggarakan secara eksternal UIN Sunan Kalijaga (SNMPTN, SPMBPTN dan SPMB PTAIN) dan ujian tulis yang diadakan secara internal oleh UIN Sunan Kalijaga (jalur regular dan jalur mandiri), sehingga jalur SPMB UIN Sunan Kalijaga dapat dibedakan menjadi 3 (tiga), yaitu: Jalur Prestasi, Jalur UTUL Eksternal dan Jalur UTUL Internal. Selain itu, mahasiswa UIN Sunan Kalijaga juga berasal dari beberapa jenis sekolah yang dapat dikelompokan menjadi 2 (dua), yaitu Sekolah Menengah Atas bersifat umum yang terdiri atas Sekolah Menengah Atas (SMA) dan Sekolah Menengah Kejuruan (SMK), serta Sekolah Menegah Atas berbasis Agama yang terdiri atas Madrasah Aliyah (MA) dan pesantren.

Berkaitan dengan penelitian ini, Muslimin (2012) menemukan bahwa jalur penerimaan berpengaruh terhadap prestasi mahasiswa di UIN Sunan Kalijaga, dimana prestasi mahasiswa jalur non TPA lebih baik dari jalur TPA sedangkan asal sekolah (SMA, SMK, dan MA) tidak berpengaruh terhadap prestasi mahasiswa. Senada, Nuswantoro (2013) juga menemukan bahwa terdapat perbedaan prestasi mahasiswa berdasarkan jalur penerimaan mahasiswa di Universitas Brawijaya. Namun, Dewi (2007) justru menemukan hal sebaliknya tentang pengaruh asal sekolah, yaitu terdapat perbedaan prestasi belajar mahasiswa Akuntansi Universitas Negeri Malang yang berasal dari SMA dan SMK.

\section{Metode Penelitian}

Penelitian ini bertujuan untuk mengetahui pengaruh jalur penerimaan dan asal sekolah dalam rangka perbaikan kualitas akademik Fakultas Sains dan Teknologi UIN Sunan Kalijaga Yogyakarta. Pendekatan yang digunakan adalah kuantitatif dengan metode ex post facto dengan desain faktorial $3 \times 2$.

Populasi yang digunakan dalam penelitian ini adalah seluruh mahasiswa Fakultas Sains dan Teknologi UIN Sunan Kalijaga. Adapun sampel yang digunakan adalah mahasiswa Fakultas Sains dan Teknologi angkatan 2009/ 2010 yang selalu aktif dalam 8 (delapan) semester sebanyak 369 mahasiswa. Sumber datanya adalah Sistem Informasi Akademik (SIA) Fakultas Sains dan Teknologi yang terdiri atas 3 (tiga) variabel, yaitu: IPK Mahasiswa, (skala 0.00 - 4.00), Jalur Penerimaan (jalur prestasi, UTUL internal, dan UTUL eksternal) dan asal sekolah (SMA/K dan MA/P).

Setelah data terkumpul, langkah selanjutnya adalah analisis data. Berikut langkah-langkahnya:

1. Pertama lakukan analisis statistik deskripsi dengan menghitung nilai rata-rata, variansi, dan standar deviasi untuk masing-masing kelompok data disertai penyajian data dalam bentuk tabel atau grafik untuk memberikan gambaran umum dari data.

2. Langkah kedua adalah melakukan analisis statistik inferensi dengan menerapkan analisis variansi 2 jalur beserta uji lanjutannya.

3. Langkah ketiga adalah melakukan analisis statistik inferensi dengan menerapkan analisis variansi 1 jalur dan uji lanjutannya.

\section{Hasil}

Dari 369 mahasiswa tersebut 38 mahasiswa diterima melalui jalur prestasi, 183 mahasiswa diterima melalui jalur UTUL internal dan 148 mahasiswa diterima melalui jalur UTUL eksternal. 283 mahasiswa berasal dari SMU/K dan 86 mahasiswa berasal dari MA/P. Berikut statistik deskriptifnya: 
Tabel 2 Statistik deskriptif IPK berdasarkan jalur penerimaan.

\begin{tabular}{ccc}
\hline Jalur Seleksi & Mean & Standar Deviasi \\
\hline Jalur Prestasi & 3.25 & 0.31 \\
Jalur Internal & 3.20 & 0.30 \\
Jalur Esternal & 3.33 & 0.26 \\
\hline
\end{tabular}

Tabel 3 Statistik deskriptif IPK berdasarkan asal sekolah.

\begin{tabular}{lcc}
\hline Asal Sekolah & Mean & Standar Deviasi \\
\hline SMA/K & 3.28 & 0.28 \\
MA/ P & 3.18 & 0.31 \\
\hline
\end{tabular}

Berdasarkan tabel 2 dan 3 di atas, diperoleh bahwa IPK mahasiswa yang diterima dari jalur eksternal lebih tinggi dari pada IPK mahasiswa yang diterima dari jalur prestasi dan IPK mahasiswa yang diterima dari jalur prestasi lebih tinggi dari IPK mahasiswa yang diterima dari jalur internal, berturutturut adalah 3,33, 3,25, dan 3,20. Sementara itu, IPK mahasiswa yang berasal dari SMU/K lebih tinggi dari IPK mahasiswa yang berasal dari MA/ P, berturut- turut adalah 3,28 dan 3,18.

Untuk membuktikan kedua pernyataan tersebut dan mengetahui ada tidaknya interaksi antara jalur penerimaan dan asal sekolah (main effect) dan interaksi perlu dilakukan analisis variansi 2 jalur.

Tabel 4 Hasil analisis ANOVA 2 jalur.

\begin{tabular}{lccc}
\hline Sumber & F & Sig & Keterangan \\
\hline Jalur Penerimaan & 6.06 & 0.03 & Terdapat Perbedaan \\
Asal Sekolah & 4.33 & 0.04 & Terdapat Perbedaan \\
Interaksi & 0.57 & 0.56 & Tidak Ada interaksi \\
\hline
\end{tabular}

Jalur Penerimaan Mahasiswa Tampak bahwa nilai sig. jalur pada tabel 4 adalah $0,003 \quad(<0.05)$, artinya pada tingkat kepercayaan 95\% Ho ditolak. Dengan demikian terdapat perbedaan IPK mahasiswa berdasarkan jalur penerimaan mahasiswa baru. Pada analisis deskriptif telah diketahui bahwa IPK mahasiswa yang diterima dari jalur eksternal lebih tinggi dari pada IPK mahasiswa yang diterima dari jalur prestasi dan IPK mahasiswa yang diterima dari jalur prestasi lebih tinggi dari IPK mahasiswa yang diterima dari jalur internal. Dan melalui uji lanjutan analisis variansi 2 arah, yang berbeda signifikan pada tingkat kepercayaan $95 \%$ adalah IPK mahasiswa yang diterima melalui jalur UTUL Eksternal dan jalur UTUL Internal.

Asal Sekolah tampak bahwa nilai sig. sekolah pada tabel 9 adalah 0,038 $(<0.05)$, artinya pada tingkat kepercayaan 95\% Ho ditolak. Dengan demikian terdapat perbedaan IPK mahasiswa berdasarkan asal sekolah mahasiswa. Pada analisis deskriptif telah diketahui bahwa IPK mahasiswa yang berasal dari SMU/K lebih tinggi dari IPK mahasiswa yang berasal dari MA/ P.

Pengaruh Interaksi (Interaction Effect), tampak bahwa nilai sig. interaksi adalah 0,568 (> 0.05), artinya pada tingkat kepercayaan 95\% Ho diterima. Dengan demikian tidak terdapat interaksi antara jalur penerimaan dan asal sekolah terhadap IPK mahasiswa. Tidak adanya interaksi antara jalur penerimaan dan asal sekolah dapat ditunjukan pada grafik gambar 2 .

Selanjutnya adalah analisis variansi 1 arah dan uji lanjutanyang digunakan untuk mengetahui pengaruh simple effect dan diperoleh hasil sebagai berikut: IPK mahasiswa yang berasal dari SMU/K dari jalur prestasi, jalur UTUL internal, dan jalur UTUL eksternal berturut-turut adalah 3,32, 3,23, dan 3,33 . 


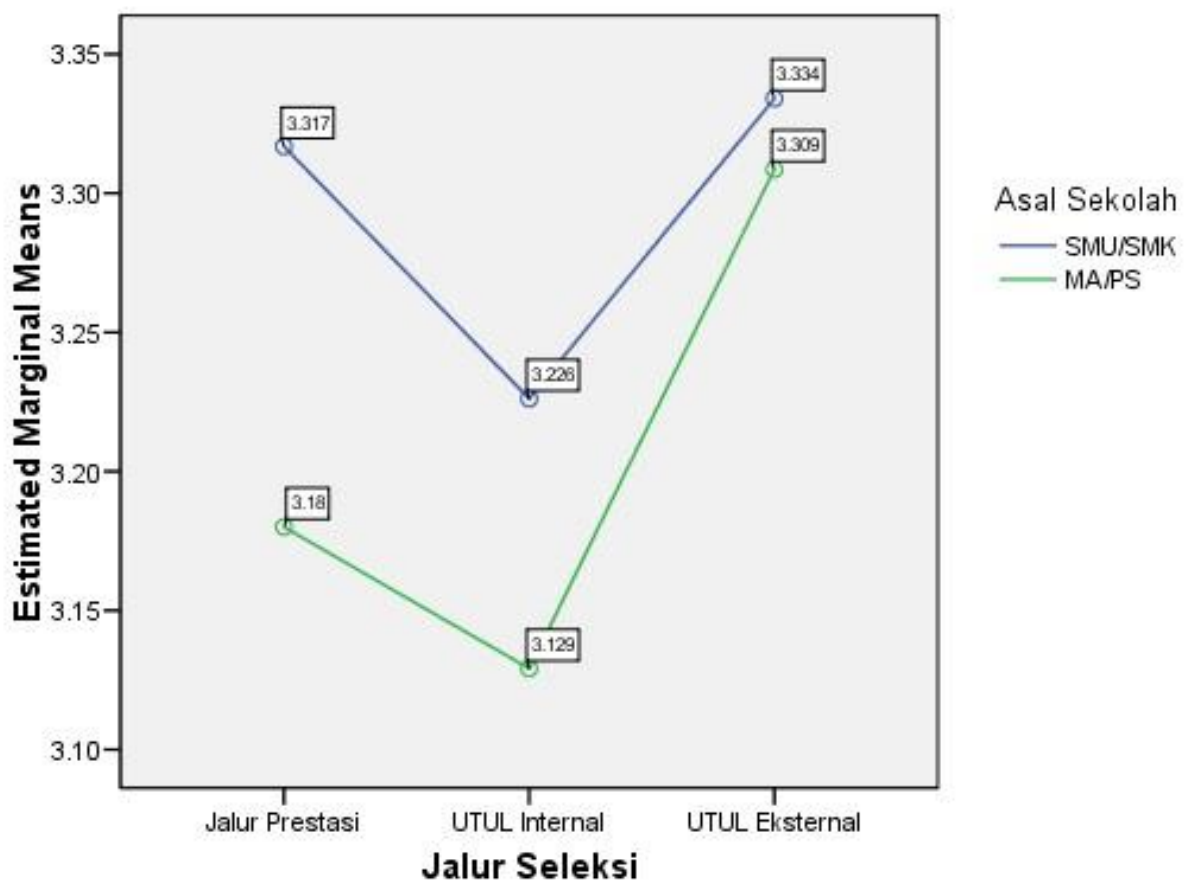

Gambar 2 Grafik interaksi jalur seleksi dan asal sekolah terhadap IPK.

Tabel 5 Hasil pengujian simple effect mahasiswa yang berasal dari SMU/K.

\begin{tabular}{llc}
\hline Jalur $\mathbf{1}$ & Jalur 2 & Keterangan \\
\hline Jalur Prestasi & Jalur UTUL Internal & Tidak Berbeda \\
Jalur Prestasi & Jalur UTUL Eksternal & Tidak Berbeda \\
Jalur UTUL Internal & Jalur UTUL Eksternal & Berbeda \\
\hline
\end{tabular}

Tampak bahwa (1) tidak terdapat perbedaan IPK mahasiswa yang berasal dari SMU/K antara mahasiswa yang diterima melalui jalur prestasi dengan jalur UTUL internal, (2) tidak terdapat perbedaan IPK mahasiswa yang berasal dari SMU/K antara mahasiswa yang diterima melalui jalur prestasi dengan jalur UTUL eksternal, (3) terdapat perbedaan IPK mahasiswa yang berasal dari SMU/K antara mahasiswa yang diterima melalui jalur UTUL internal dengan jalur UTUL eksternal, dimana prestasi mahasiswa yang diterima melalui UTUL eksternal lebih baik daripada mahasiswa yang diterima melalui UTUL internal.

IPK mahasiswa yang berasal dari MA/P dari jalur prestasi, jalur UTUL internal, dan jalur UTUL eksternal berturut-turut adalah 3,18, 3,13, dan 3,31.

Tabel 6 Hasil pengujian simple effect mahasiswa yang berasal dari MA/P

\begin{tabular}{llc}
\hline Jalur $\mathbf{1}$ & Jalur $\mathbf{2}$ & Keterangan \\
\hline Jalur Prestasi & Jalur UTUL Internal & Tidak Berbeda \\
Jalur Prestasi & Jalur UTUL Eksternal & Tidak Berbeda \\
Jalur UTUL Internal & Jalur UTUL Eksternal & Berbeda \\
\hline
\end{tabular}

Tampak bahwa (1) tidak terdapat perbedaan IPK mahasiswa yang berasal dari MA/P antara mahasiswa yang diterima melalui jalur prestasi dengan jalur UTUL internal, (2) tidak terdapat perbedaan IPK mahasiswa yang berasal dari MA/P antara mahasiswa yang diterima melalui jalur prestasi dengan jalur UTUL eksternal, (3) terdapat perbedaan IPK mahasiswa yang berasal dari MA/P antara mahasiswa 
yang diterima melalui jalur UTUL internal dengan jalur UTUL eksternal, dimana prestasi mahasiswa yang diterima melalui UTUL eksternal lebih baik daripada mahasiswa yang diterima melalui UTUL internal.

IPK mahasiswa yang diterima melalui jalur prestasi berasal dari jalur SMU/K dan MA/P berturutturut adalah 3,32 dan 3,18. Berdasarkan tabel 13 diperoleh bahwa diperoleh bahwa pada tingkat kepercayaan 95\%, tidak terdapat perbedaan IPK mahasiswa yang diterima melalui jalur prestasi baik mahasiswa yang berasal dari SMU/K maupun yang berasal dari MA/P.

IPK mahasiswa yang diterima melalui jalur UTUL internal berasal dari jalur SMU/K dan MA/P berturut-turut adalah 3,23 dan 3,13. Berdasarkan tabel 13 diperoleh bahwa diperoleh bahwa pada tingkat kepercayaan 95\%, terdapat perbedaan IPK mahasiswa yang diterima melalui jalur UTUL internal antara mahasiswa yang berasal dari SMU/K maupun yang berasal dari MA/P, dimana mahasiswa yang berasal dari SMU/K lebih baik dari mahasiswa yang berasal dari MA/ P.

IPK mahasiswa yang diterima melalui jalur UTUL eksternal berasal dari jalur SMU/K dan MA/P berturut-turut adalah 3,33 dan 3,31. Berdasarkan tabel 13 diperoleh bahwa diperoleh bahwa pada tingkat kepercayaan 95\%, tidak terdapat perbedaan IPK mahasiswa yang diterima melalui jalur UTUL eksternal baik mahasiswa yang berasal dari SMU/K maupun yang berasal dari MA/P.

\section{Pembahasan}

\section{Jalur Penerimaan}

Penelitian ini membagi jalur penerimaan menjadi 3 (tiga): yaitu jalur prestasi, jalur UTUL internal, dan jalur UTUL eksternal. Diperoleh bahwa terhadap pengaruh jalur penerimaan terhadap prestasi mahasiswa di Fakultas Sains dan Teknologi UIN Sunan Kalijaga tahun ajaran 2009/2010 setelah menjalani proses pembelajaran selama 4 (empat) tahun atau 8 (delapan) semester yang diukur menggunakan nilai Indeks Prestasi Komulatif (IPK).

Perbedaan terjadi pada mahasiswa yang diterima melalui jalur UTUL internal dengan jalur UTUL Eksternal, yaitu prestasi mahasiswa yang diterima melalui jalur UTUL eksternal lebih baik dibanding mahasiswa yang diterima melalui jalur UTUL internal. Sedangkan prestasi mahasiswa yang diterima melalui jalur prestasi dengan jalur UTUL internal dan prestasi mahasiswa yang diterima melalui jalur prestasi dengan jalur UTUL eksternal tidak berbeda. Perbedaan prestasi ini berlaku secara umum dan juga berlaku dalam pengaruh sederhana (simple effect) pada mahasiswa yang berasal dari SMU/K serta mahasiswa yang berasal dari MA/Pesantren.

Jalur UTUL internal adalah jalur penerimaan mahasiswa baru yang diselenggarakan secara mandiri oleh UIN Sunan Kalijaga yang meteri ujian tulisnya meliputi Tes Potensi Akademik (tes verbal, tes numerik, tes spasial/ figural) dan tes Dirosah Islamiah. Sedangkan jalur UTUL eksternal adalah jalur penerimaan mahasiswa baru yang dipersiapkan dan diselengarakan di luar UIN Sunan Kalijaga dan secara khusus berada di bawah koordinasi konsersium nasional perguruan tinggi yang materinya meliputi tes kemampuan dasar (matematika dasar, bahasa Indonesia, dan Bahasa Inggris) dan tes kemampuan IPA untuk mahasiswa yang masuk di Fakultas Sains dan Teknologi.

Hasil penelitian ini mirip dengan penelitian yang dilakukan Muslimin (2012), yang menyatakan bahwa prestasi mahasiswa yang diterima melalui jalur non TPA (jalur prestasi dan jalur UTUL eksternal (SNMPTN)) lebih baik dari pada mahasiswa yang diterima melalui jalur UTUL internal. Juga mirip dengan penelitian Nuswantoro (2013) yang menyatakan prestasi mahasiswa yang diterima dari jalur SNMPTN (jalur UTUL eksternal) lebih baik dari jalur prestasi dan jalur sistem seleksi yang dilakukan Universitas Brawijaya (Jalur UTUL internal)

Beberapa kemungkinan penyebab prestasi belajar mahasiswa yang diterima dari jalur UTUL internal tidak lebih baik dari jalur lainnya adalah instrument tes yang digunakan untuk menyeleksi calon mahasiswa melalui jalur UTUL internal belum memiliki daya prediksi yang baik. Asumsi ini didasarkan atas penelitian Fathurahman dan Muslimin (2008) yang melakukan uji kualitas aitem TPA tahun 2007 yang merupakan salah satu tes ujian masuk menyatakan bahwa aitem-aitem TPA 2007 banyak yang tidak berkualitas. 


\section{Asal Sekolah}

Secara umum, asal sekolah mahasiswa yang masuk UIN Sunan Kalijaga dibagi menjadi 4 (empat), yaitu: SMU bertujuan diantara menyediakan dan menyiapkan siswa/i yang hendak melanjutkan studi ke jenjang yang lebih tinggi; akademi atau perguruan tinggi. Sedangkan SMK lebih ditujukan untuk menyediakan tenaga kerja tingkat menengah, dan MA/ Pesanteren, sebagaimana SMU bertujuan untuk mengantarkan siswa memasuki perguruan tinggi umum maupun perguruan tinggi Islam.

Pada penelitian ini membagi asal sekolah mahasiswa menjadi 2 (dua), yaitu SMU/K dan MA/ Pesanteren. Diperoleh bahwa terhadap pengaruh asal sekolah terhadap prestasi mahasiswa di Fakultas Sains dan Teknologi UIN Sunan Kalijaga tahun ajaran 2009/ 2010, yaitu prestasi akademik mahasiswa yang berasal dari SMU/K lebih tinggi dibanding mahasiswa yang berasal dari MA/P. Setelah diselidiki lebih lanjut dalam pengaruh sederhana (simple effect), perbedaan prestasi antara mahasiswa yang berasal dari SMU/K dengan mahasiswa yang berasal dari MA/P terjadi pada jalur UTUL Internal. Sedangkan pada jalur prestasi dan jalur UTUL eksternal, baik mahasiswa yang berasal dari SMU/K maupun mahasiswa yang berasal dari MA/P memiliki prestasi akademik yang berbeda.

Kemungkinan penyebab prestasi belajar mahasiswa yang berasal dari MA/P lebih rendah dari pada mahasiswa yang berasal dari SMU/K adalah karakteristik Fakultas Sains dan Teknologi yang di dalamnya terdapat program studi-program studi umum, seperti: Biologi, Fisika, Kimia, Matematika, Pendidikan Biologi, Pendidikan Fisika, Pendidikan Kimia, Pendidikan Matematika, Tehnik Industri, dan Tehnik Informatika.

\section{Kesimpulan}

Berdasarkan uraian di atas diperoleh beberapa kesimpulan sebagai berikut:

1. Jalur penerimaan berpengaruh terhadap prestasi mahasiswa, dimana prestasi mahasiswa yang diterima melalui jalur eksternal lebih baik dari jalur internal.

2. Asal sekolah berpengaruh terhadap prestasi mahasiswa dimana prestasi mahasiswa yang berasal dari SMU/K lebih baik dari MA/P.

3. Tidak terdapat interaksi antara kedua faktor tersebut dalam mempengaruhi prestasi mahasiswa.

\section{Referensi}

[1] Dewi A, C., 2007. Pengaruh Jenis Asal Sekolah Menengah Terhadap Kinerja Kuliah Mahasiswa Pendidikan Akuntansi Universitas Negeri Malang. Skripsi, Jurusan Pendidikan Akuntansi, Fakultas Ekonomi, Universitas Negeri Malang. Pembimbing: (1) DR. Bambang Sugeng, S.E, M.A, M.M, Ak (2) Sawitri Dwi Prastiti, S.E, M.Si, Ak.

[2] Gojali, I dan Umiarso, 2011. Manajemen Mutu Sekolah di Era Otonomi Pendidikan. IRCiSoD: Jogjakarta

[3] Muslimin, Z.I., 2012. Prestasi Belajar Mahasiswa Ditinjau dari Jalur Penerimaan mahasiswa Baru, Asal Sekolah, dan Skor Tes Potensi Akademik. Jurnal Penelitian Psikologi Vol. 03, No. 01, 381-393.

[4] Nuswantoro, A.B., 2013. Hubungan Jalur Penerimaan Mahasiswa baru Akuntasi terhadap Prestasi Akademik Fakultas Ekonomi, Universitas Brawijaya Malang. Pembimbing: Prof. Dr. Unti Lugigdo, Ak

[5] Pasaribu, L.L,. 1983. Proses Belajar. Bandung: Tarsito

[6] Slameto, 2003. Belajar dan Faktor-faktor yang Mempengaruhinya, PT. Rineka Cipta: Jakarta

[7] Tirtonegoro. S., 2001. Anak Supernormal dan Program Pendidikannya. Jakarta: Bumi Aksara

[8] UIN Sunan Kalijaga, 2004. Kerangka Dasar Keilmuan \& Pengembangan Kurikulum UIN. Yogyakarta: Pokja Akademik UIN Sunan Kalijaga

[9] UIN Sunan Kalijaga, 2009. Sistem Penerimaan Mahasiswa Baru Tahun Ajaran 2009/ 20010 UIN Sunan Kalijaga. Yogyakarta: Pokja Akademik UIN Sunan Kalijaga.

[10] Winke, W.S., 1996. Psikologi Pendidikan dan Evaluasi Belajar. Jakarta: Gramedia. 